\title{
RELATIONSHIPS BETWEEN FREE-LIVING AMOEBA AND THEIR INTRACELLULAR BACTERIA
}

\author{
Ilze Rubeniṇa ${ }^{1,2, \#}$, Muza Kirjušina ${ }^{1,2}$, Aivars Bērziņš² ${ }^{2}$ Olga Valciṇa², \\ and Inese Jahundoviča ${ }^{1,2}$ \\ ${ }^{1}$ Daugavpils University, Institute of Life Sciences and Technology, 1A Parādes Str., Daugavpils, LV-5401, LATVIA; \\ muza.kirjusina@du.Iv, inese.jahundovica@du.Iv \\ ${ }^{2}$ Institute of Food Safety, Animal Health and Environment "BIOR", 3 Lejupes Str., Riga, LV-1076, LATVIA; \\ aivars.berzins@bior.lv, olga.valcina@bior.lv \\ *Corresponding author, ilze.rubenina@du.Iv
}

Communicated by Arvīds Barševskis

\begin{abstract}
An increasing number of bacteria have been described as benefiting from interaction with freeliving amoeba. The most common association between free-living amoeba and microorganisms is interaction of various non-pathogenic and pathogenic bacterial species with amoeba. Various pathogenic bacterial species have capacity to resist digestion by free-living amoeba, which has been observed by many researchers. Also, several of these pathogens are able to resist digestion by macrophages. In addition, free-living amoeba have been associated with several diseases in humans. Acanthamniioeba castella is an important predator of bacteria. It is a ubiquitous organism in water, soil, and air. Attention from a public health perspective is needed by investigation of interaction of foodborne pathogens and free-living amoeba. Bacteria can use free-living amoeba as reservoirs, mediators or vehicles, an infection route, "biological gym" and evolutionary crib or interaction may result in a close endosymbiotic relationship. The purpose of this review is to describe the interaction mechanisms between free-living amoeba and common bacteria species that survive in host cells.
\end{abstract}

Key words: Acanthamoeba, endosymbiosis, endoparasites, resistance, "biological gym".

\section{INTRODUCTION}

Free-living amoebae (FLA) are unicellular, ubiquitous micro-organisms found in diverse habitats like marine water, freshwater, soil, air, and man-made environments (Schmitz-Esser et al., 2010). They are mobile and feed on various microorganisms, such as fungi, protozoa, bacteria, and organic particles (Cateau et al., 2014). Many wellknown pathogens of humans are able to infect, survive, and multiply within phagocytosis vacuoles (Greub and Raoult, 2004; Horn and Wagner, 2004). FLA serve as reservoirs and vectors for the transmission of pathogenic bacteria to humans or animals (Lorenzo-Morales et al., 2007; Thomas and Greub 2010; Anacarso et al., 2012; Mella et al., 2016). Several publications appeared in recent years documenting that amoeba can serve as a genetic "melting pot" where gene exchanges occur. Amoeba also may participate in these gene exchanges (Grillot-Courvalin et al., 1998; Moreira and Brochier-Armanet, 2008). Interaction between FLA and bacteria promotes the pathogenicity of bacteria, and amoeba were important for the adaptation of bacteria to higher eukaryotic cells via intracellular growth (Harb et al., 2000; Albert-Weissenberger et al., 2007). An intracellular lifestyle protect bacteria against adverse conditions and disinfectants and some bacteria species are capable to survive in amoeba even during the cyst stage (Borella, 2005; Thomas and Greub, 2010; Melle et al., 2016). However, not all bacteria are ingested or digested by amoeba. Intracellular bacteria have evolved various adaptations to escape ingestion by amoeba and exploit host cell resources (Huws et al., 2008). Intracellular bacteria called also amoeba-resisting bacteria (ARB), use the amoeba as a "training ground" for resistance to destruction by macrophages (Greub and Raoul, 2004; Thomas et al., 2006). An effective tool to detect ARB is co-culture with amoeba (Kebbi-Beghdadi and Greub, 2014). Mostly water (cooling towers, hospital water supplies, rivers, lakes, domestic water supplies and others) and soil have been investigated as possible reservoirs of ARB using the co-culture method described by Pagnier et al., 2008. Aquatic ecosystems around human settlements are recognised as a reservoir for ARB (Pagnier et al., 2008; Xi et al., 2009. There are various studies (Rowbotham, 1998; 
Greub et al., 2004; Collingro et al., 2005; Thomas et al., 2006; Pagnier et al., 2008) that showed that ARB can be a useful tool for recovering potentially pathogenic bacteria. Previous studies indicated that four species of FLA have an association with human disease: Naegleria fowleri, Sappinia diploidea, Balamuthia mandrillaris and Acanthamoeba spp. These opportunistic pathogens cause fatal human infections involving the central nervous system $(N$. fowleri, B. mandrillaris and Acanthamoeba spp.), acute and fulminating meningoencephalitis ( $N$. fowleri), encephalitis (S. diploidea) and keratitis (Acanthamoeba spp.) (SchmitzEsser et al., 2008; Siddiqui and Khan, 2012a; 2012b). A limited number of studies are available on amoeba biodiversity, because most of them are difficult to recover and a low number of microbiological and molecular methods or specific assays that allow to detect the specific FLA species have been developed. More research into FLA (including species other than Acanthamoeba spp.) morphology, physiology and genetic are still necessary. It is important to identify characteristic features for each amoeba species that will facilitate determination of taxa, as amoeba classification requires more research. If we have only analysis of morphology and information on a few genes, then it is not possible to locate amoeba within the eukaryotic tree in an accurate manner. Due to changes in our understanding of phylogenetic lineages of eukaryotes, many of the traditional systematic groups remain no longer valid. Modern morphological approaches and molecular phylogenetic classification of the amoeba differ due to diverese biochemical pathways. According to Cavalier-Smith (2004) and Adl et al. (2005; 2012) classification of unicellular eukaryotes, the amoeba belong to the Eukaryota domain Amoebozoa kingdom Amoebozoa phylum. The Phylum was divided into two subphyla's: Conosa and Lobosa, which included typical lobose amoeba. Subphylum are divided in many orders such as Tubulinida, Amoebida and others. Families of naked lobosoans are based on their morphology. Number of families are floating, however; some of these families have remained unchanged, such as Amoebidae, Vannellidae, and Acanthamoebidae and others. Genera of amoeba are not clearly identified, however, one of the commonly isolated is Acanthamoeba (Cavalier-Smith, 2004; Adl et al., 2005; 2012). Comprehensive FLA classification shown in Table 1.

There are several studies indicating the relevance of the bacterial-amoeba interaction. FLA are still discovered in new habitats, including anthropogenic environments like refrigerators, taps, toothbrush, dishcloths and others. Therefore, from a public health perspective it is important to investigate relationships between FLA and non-pathogenic or pathogenic bacteria, due to frequent contact with human and animals. However, bacteria are developing many new adaptive traits for changing environmental conditions, which creates difficulty in understanding bacteria-amoeba relationships completely.

\section{INTERACTION BETWEEN FLA AND BACTERIA}

Amoeba are able to interact with pathogenic bacteria in various ways. There are numerous studies (e.g. Barker and Brown, 1994; Vaerewijck et al., 2008; 2010; 2014; Thomas and Greub, 2010) that one such way is FLA acting as vehicles and fill with living bacteria, in a process called "Trojan horses". Another way is that bacteria are able to resist FLA digestion and live in trophozoites or cysts (Greub and Raoult, 2004; Cateau et al., 2014). Furthermore, it is possible that interactions could occur when bacteria manipulate host gene expression of housekeeping genes and enable themselves to proliferate in amoeba cells. Bacterial interaction with amoeba has been associated with increase in antimicrobial resistance of bacterial pathogens (Cirillo et al., 1997). Therefore, FLA may be viewed as a "biological gym" where bacterial pathogens are continuously trained to

Table 1

CLASSIFICATION OF FREE LIVING AMOEBA*

\begin{tabular}{|c|c|c|c|c|}
\hline Domain & Kingdom & Family & Genus & Examples \\
\hline \multirow{9}{*}{ Eukaryota } & \multirow{9}{*}{ Amoebozoa } & Acanthamoebidae & Acanthamoeba & $\begin{array}{l}\text { A. astronyxis } \\
\text { A. castellani } \\
\text { A. culbertsoni } \\
\text { A. mauritaniensis } \\
\text { A. polyphaga } \\
\text { A. rhysodes } \\
\end{array}$ \\
\hline & & Dictyosteliidae & Dictyostelium & D. discoideum \\
\hline & & Endamoebidae & Entamoeba & E. histolytica \\
\hline & & N/A & Ehinamoeba & Ehinamoeba spp. \\
\hline & & \multirow{2}{*}{ Hartmannellidae } & Hartmanella & H. vermiformis \\
\hline & & & Vermamoeba & V. vermiformis \\
\hline & & \multirow{2}{*}{ Vahlkamphiidae } & Vahlkamphia & V. avara \\
\hline & & & Naegleria & N. gruberi \\
\hline & & Thecamoebidae & Thecamoeba & T. quadrilineata \\
\hline
\end{tabular}

* According to Cavalier-Smith, 2004; Adl et al., 2005; 2012 
be more resistant on impact with more developed host cells. Since ARB can exchange genetic material with other intracellular bacteria and develop virulence traits, FLA are used as an evolutionary crib, which explains their adaptation for survival within macrophages (Harb et al., 2000; Huws et al., 2008; Kebbi-Beghdadi and Greub, 2014). A selective agent that determines features that are relevant for bacterial survival and evolution is predation (Matz and Kjelleberg, 2005). Interaction between FLA and bacteria promotes survival of bacteria under grazing pressure, and therefore bacteria develop new adaptive features such as cell-to-cell communication, microcolony formation, swimming speed and bioactive metabolites (Matz et al., 2004). Due to morphological traits of bacteria, such as motility, high abundance and small size, they easily interact with various FLA. Bacteria needs to develop pre- (extracellular) and post- (intracellular) ingestional adaptions to survive in food vacuoles (Jürgens and Matz, 2002). Huws et al. (2008) noted that in $1 \%$ amoeba, intracellular replication of Salmonella occurred only in the contractile vacuole. One of the extracellular features of amoeba-bacterial interaction is a massive and oversized morphology. Bacteria such as Comamonas acidovorans develop non-digestible filamentous cells. A second adaptive trait is increased bacterial motility. Bacteria can achieve a high swimming speed and a "run and reversal" swimming pattern if they contact a predator. This mechanism acts as a resistance strategy to escape from FLA grazing (Jürgens and Matz, 2002). Another adaptive feature is cell-cell contact by membrane-bound receptors. The bacterial cell surface develops specific biochemical structures and unspecific interaction forces, and form grazing-resistant morphological structures, such as filaments and aggregates (Matz and Jürgens, 2003). For example, long pili mediate Legionella adhesion to the host cell (Koval, 1993). Surface properties are essential for bacteria because feeding is based on interaction at the cell-cell interface, e.g., Acanthamoeba has carbohydrate-sensitive sites on the cell surface. These sites help in the phagocytosis process, because some bacteria are coated with specific biochemical components such as polysaccharides or proteins (Jürgens and Matz, 2002). This means that food selection is based on the recognition of specific bacterial biochemical surface compounds (Matz and Jürgens, 2003).

Intracellular adaptive features developed in response to acid and enzymatic degradation. One of the mechanisms is enzymatic resistance to avoid digestion. The protective function of microbial S-layers allows Synechococcus cells to resist chemical degradation and digestion in Tetrahymena. The bacteria Janthinobacterium lividum and Chromobacterium violaceum have developed more effective resistance mechanisms than for Synechococcus cells. They release bioactive metabolites upon digestion, which cause rapid death and lysis (Koval, 1993; Matz and Kjelleberg, 2005). In amoeba and human macrophages, bacteria such as Listeria, Rickettsia, Mycobacterium, Legionella and Chlamydia use related mechanisms to survive in cells. Amoeba and macrophages have similar phagocytic mechanisms, such as prey recogni- tion by cell surface receptors and killing of prey by oxygen radicals (Barker and Brown, 1994).

M. avium enters in amoeba by a complement-independent mechanism of uptake. Intracellular growth causes various physiological changes. These bacteria promote entry into amoeba by upregulation of a factors that is directly involved in entry, like as-yet-unidentified entry factors, or downregulation or modification of a gene product(s). During the first 15 min after Acanthamoeba infection, M. avium bacteria is admitted into individual vacuoles, which are later fused into one large vacuole. Alteration occurs with expression of the gene involved in entry while bacteria grow in the host cell. Due to the prevention of lysosomal fusion in a similar manner to that observed in macrophages, M. avium is able to survive and replicate in amoeba cells. Cirrilo et al. (1997) found that replication of $M$. avium occurs at temperatures as low as $24^{\circ} \mathrm{C}$ and that growth and interaction of $M$. avium with FLA can increase virulence. One of the interaction mechanisms by which $M$. avium spreads in the environment is the killing of infected amoeba (Koval, 1993; Cirillo et al., 1997; Matz and Jürgens, 2003). Salah et al. (2009) provided a list of Mycobacterium species that were isolated from amoebal co-cultures. Amoeba models allowed to investigate bactericidal mechanisms, phagocytosis and surface receptors. All tested Mycobacterium species were phagocytosed and were able to penetrate into amoebal vacuoles, including some species like $M$. tuberculosis that could survive in cysts under aerobic conditions (Salah et al., 2009). Endoparasites of FLA Legionella enter macrophages or amoeba by coiling phagocytosis after which it enters the phagosome. Proteins encoded by the Dot/Icm type IV secretion system genes are secreted by Legionella and they inhibit lysosome adhesion and phagosome maturation. Components from rough endoplasmic reticulum prevent lysosome adhesion and acidification of vesicles by the phagosome, protecting bacteria from attack. Legionella replicates and when amino acid deficiency occurs the FLA release the bacteria (Taylor et al., 2009). Pathogenic chlamydiae enter and replicate in protozoa supported by the type III secretion system associated with pathogenicity, but $L$. pneumophila has receptors such as putative galactose/ $N$-acetylgalactosamine (Gal/GalNAc) lectin that mediate the attachment to the host cell. The amoeba has cup-shaped invaginations (zipper phagocytosis) on the cell surface that uptake various microorganisms. After ingestion, bacteria release the Dot/Icm type IV secretion system, which transfers macromolecules into the host cell to evade endocytic fusion (Molmeret et al., 2005). This secretion system is required for intracellular growth (Christie and Volgel, 2000). Also, the amoeba form of Dictyostelium discoideum supports intracellular replication of L. pneumophila. D. discoideum cells infected by Legionella-containing vacuole cause transformation of rough endoplasmic reticulum, which prevents Legionella-containing vacuole fusion with lysosomes. The Dot/Icm type IVb secretion supports modulation of host cell functions and mediates transfer of bacterial proteins into eukaryotic host cells (Molmeret et al., 2005). 
For genetic exchange and the supply of effector molecules to eukaryotic cells, bacteria use type IV secretion systems, such as VirB/VirD4 (pTi) or Trw, cagPAI, Ptl or Dot/Icm (Cascales and Christie, 2003). One of the most important adaptive mechanisms is by obtaining a gene, as it promotes intracellular growth, induces the synthesis of nutrients and prevents defence mechanisms. To export substrate molecules to a wide range of target cells during infection, pathogens such as Bordetella pertussis, L. pneumophila, Brucella spp., Bartonella spp., Coxiella burnetii and Helicobacter pylori use type IV machines (Christie and Volgel, 2000).

FLA are used by bacteria as transmission reservoirs, mediators, vectors or vehicles (Table 2) (Siddiqui and Khan, 2012b; Cateau et al., 2014; Vezzulli et al., 2014). Declerck et al. (2009) confirmed that in anthropogenic aquatic systems, A. castellanii play a decisive role in the increase and spread of L. pneumophila. There are several known interaction mechanisms, such as actin rearrangement, amoeba cell surface adhesion to microorganisms, coding of sugar-manipulating enzymes, amoeba genotype virulence and host cell morphogenetic changes. These interaction mechanisms provide disease (such as Q fever, preventable blindness, sexually transmitted diseases, bronchiolitis) dispersal routes, which are common in man-made and food-related environments (Cavalier-Smith et al., 2004; Thomas and Greub, 2010).

\section{CONCLUSIONS}

Among the discovered FLA species, S. diploidea, $B$. mandrillaris, Acanthamoeba and N. fowleri are opportunistic pathogens. Several studies indicated that amoeba may play roles as mediator, vector, "Trojan horse" or "biological gymnasia". Many bacteria are able to penetrate into amoeba cell, although research results are still few and conflicting. Future studies are required to study the genes regulated by bacteria growth, which may provide better understanding of the factors responsible for bacteria entry, intracellular survival, replication and release. However, not all interaction mechanisms between FLA and bacteria are fully described, due to both technical limitation and relative low number of samples tested. Therefore, in future studies a higher number of samples should be used. Also, environmental and clinical studies are required to estimate conditions that allow bacteria to penetrate, survive and proliferate in host cell. Thus, co-culture should be used to discover new pathogenic bacterial species, due to amoeba's major role on the composition of microbiota.

SUMMARY OF INTERACTION BETWEEN FREE LIVING AMOEBA AND BACTERIA

\begin{tabular}{|c|c|c|}
\hline Species of FLA & Bacteria & Interaction mechanism and references \\
\hline $\begin{array}{l}\text { Acanthamoeba } \\
\text { astronyxis }\end{array}$ & Helicobacter pylori & $\begin{array}{l}\text { Reservoir } \\
\text { (Siddiqui and Khan, 2012a) }\end{array}$ \\
\hline \multirow{3}{*}{ A. castellanii } & Shigella dysenteriae, S. flexneri, S. sonnei & $\begin{array}{l}\text { Reservoir (transmission reservoir) } \\
\text { (Saeed et al., 2009; 2012) }\end{array}$ \\
\hline & $\begin{array}{l}\text { Acinetobacter baumannii, Bosea sp., Campylobacter jejuni, C. coli, } \\
\text { Coxiella burnetii, Francisella tularensis, Kocuria kristinae, Roseomonas } \\
\text { gilardii }\end{array}$ & $\begin{array}{l}\text { Reservoir } \\
\text { (Baron } \text { et al., 1980; Hackstadt and Williams, 1983; } \\
\text { Snelling } \text { et al., 2006; Thomas } \text { et al., 2010; Saeed } \text { et } \\
\text { al., 2012; Cateau } \text { et al., 2014) }\end{array}$ \\
\hline & Yersinia enterocolitica & $\begin{array}{l}\text { Increased disinfection resistance when internalized } \\
\text { (Snelling et al., 2006) }\end{array}$ \\
\hline A. culbertsoni & Acinetobacter baumannii, Mobiluncus curtisii & $\begin{array}{l}\text { Reservoir } \\
\text { (Thomas et al., 2010; Cateau et al., 2014) }\end{array}$ \\
\hline \multirow{2}{*}{ A. polyphaga } & $\begin{array}{l}\text { Mycobacterium abscessus, M. avium subsp. avium, M. aurum, M. } \\
\text { bohemicum, M. chelonae, M. fortuitum, M. gastri, M. goodii, M. gordonae, } \\
\text { M. immunogenum, M. intracellulare, M. kansasii, M. lentiflavum, M. } \\
\text { mageritense, M. malmoense, M. marinum, M. massiliense, M. } \\
\text { mucogenicum, M. peregrinum, M. porcinum, M. septicum, M. simiae, M. } \\
\text { smegmatis, M. szulgai, M. terrae, M. tusciae, Shigella dysenteriae, S. } \\
\text { flexneri, S. sonnei }\end{array}$ & $\begin{array}{l}\text { Reservoir (transmission reservoir) (Adekambi et al., } \\
\text { 2006; Saeed } \text { et al., 2009; 2012) }\end{array}$ \\
\hline & $\begin{array}{l}\text { Aeromonas eucrenophila, A. salmonicida, Agrobacterium tumefaciens, } \\
\text { Bosea spp., Bradyrhizobium spp., Burkholderia cepacia, Chryseobacterium } \\
\text { indologenes, } \\
\text { Klebsiella variicola, Pseudomonas mendocina, Rasobacterium spp., } \\
\text { Simkania negevensis, Sphingobacterium multivorum, Staphylococcus } \\
\text { pasteuri }\end{array}$ & $\begin{array}{l}\text { Reservoir } \\
\text { (Snelling } \text { et al., 2006; Thomas } \text { et al., 2010) }\end{array}$ \\
\hline \multirow{2}{*}{ A. rhysodes } & Salmonella spp. & $\begin{array}{l}\text { Mediator } \\
\text { (Vaerewijck et al., 2014) }\end{array}$ \\
\hline & Salmonella enterica & \begin{tabular}{|l} 
Reservoir \\
(Tezcan-Merdol et al., 2004)
\end{tabular} \\
\hline Acanthamoeba spp. & Legionella pneumophila & $\begin{array}{l}\text { Reservoir, vector and vehicle } \\
\text { (Cirrillo } \text { et al., 1997; Harb et al., 2000; Schuster et } \\
\text { al., 2002; 2004; Dalebroux et al., 2009; Iseberg et al., } \\
\text { 2009; Dupuy et al., 2011) }\end{array}$ \\
\hline
\end{tabular}


Table 2 (continued)

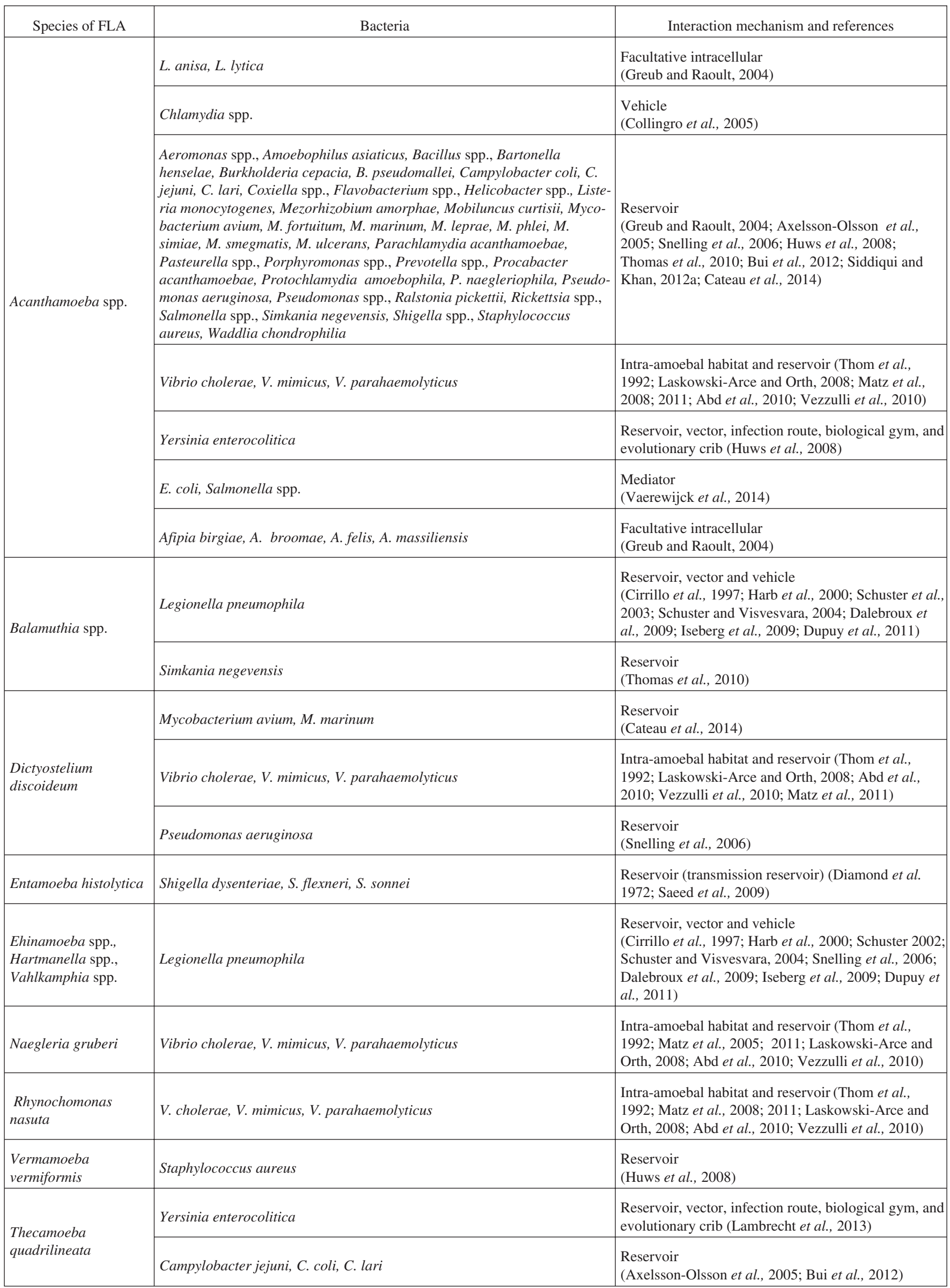




\section{ACKNOWLEDGEMENTS}

This work was supported by National Research Programme No. 7, Agricultural Resources for Sustainable Production of Qualitative and Healthy Foods in Latvia (AgroBioRes) project No. 5 "Resistance of microorganisms and other biological and chemical risks research procedures development and application in the food chain (RISKS)".

\section{REFERENCES}

Abd, H., Valeru, S. P., Sami, S. M., Saeed, A., Raychaudhuri, S., Sandström, G. (2010). Interaction between Vibrio mimicus and Acanthamoeba castellani. Environ. Microbiol. Rep., 2, 166-171.

Adekambi, T., Salah, S. B., Khlif, M., Raoult, D., Drancourt, M. (2006). Survival of environmental mycobacteria in Acanthamoeba polyphaga. Appl. Environ. Microbiol., 72 (9), 5974-5981.

Adl, S. M, Simpson, A. G. B., Lane, C. E., Lukeš, J., Bass, D., Bowser, S. S., Brown, M., Burki, F., Dunthorn, M., Hampl, V., Heiss, A, Hoppenrath, M., Lara, E., IeGall, L., Lynn, D. H., McManus, H., Mitchell, E. A. D., Mozley-Stanridge, S. E., Wegener Parfrey, L., Pawlowski, J., Rueckert, S., Shadwick, L., Schoch, C., Smirnow, A., Spiegel, F. W. (2012). The revised classification of eukaryotes. J. Eukaryot. Microbiol., 59, 429-493.

Adl, S. M., Simpson, A. G., Farmer, M. A., Andersen, R. A., Anderson, O. R., Barta, J. R., Bowser, S., Brugerolle, G., Fensome, R. A., Frederic, S., James, T. Y., Karpov, S., Kurgens, P., Krug, J., Lane, C. E., Lewis, L.A., Lodge, J., Mozley-Standridge, S. E., Nerad, T. A., Shearer, C. A., Smirnow, A. V., Spiegel, F. W., Taylor, M. F. J. R. (2005). The new higher level classification of eukaryotes with emphasis on the taxonomy of protists. J. Eukaryot. Microbiol., 52, 399-451.

Albert-Weissenberger, C., Cazalet, C., Buchrieser, C. (2007). Legionella pneumophila - a human pathogen that co-evolved with fresh water protozoa. Cell. Mol. Life Sci., 64, 432-448.

Anacarso, I., de Niederhausern, S., Messi, P., Guerrieri, E., Iseppi, R., Sabia, C., Bondi, M. (2012). Acanthamoeba polyphaga, a potential environmental vector for the transmission of food-borne and opportunistic pathogens. $J$. Basic Microbiol., 52, 261-268.

Axelsson-Olsson, D., Waldenström, J., Broman, T., Olsen, B., Holmberg, M. (2005). Protozoan Acanthamoeba polyphagaas a potential reservoir for Campylobacter jejuni. Appl. Environ. Microbiol., 71 (29), 987-992.

Barker, J., Brown, M. R. (1994). Trojan horses of the microbial world: Protozoa and the survival of bacterial pathogens in the environment. Microbiology, 140, 1253-1259.

Baron, D., Danglot, C., Vilaginés, R. (1980). Role of a free-living amoeba from water, Acanthamoeba castellani, in the transport of naked or enveloped animal viruses. C. R. Seances Acad. Sci., III, 291 (7), 629-632.

Borella, P., Guerrieri, E., Marchesi, I., Bondi, M., Messi, P. (2005). Water ecology of Legionella and protozoan: Environmental and public health perspectives. Biotechnol. Annu. Rev., 11, 355-380.

Bui, X. T., Winding, A., Qvortrup, K., Wolff, A., Bang, D. D., Creuzenet, C. (2012). Survival of Campylobacter jejuni in co-culture with Acanthamoeba castellanii: Role of amoeba-mediated depletion of dissolved oxygen. Environ. Microbiol., 14 (8), 2034-2047.

Cascales, E., Christie, P. J. (2003). The versatile bacterial type IV secretion systems. Nat. Rev. Microbiol., 1, 137-149.

Cateau, E., Delafont, V., Hechard, Y., Rodier, M. H. (2014). Free-living amoebae: What part do they play in healthcare-associated infections? $J$. Hosp. Infect., 87, 131-140.

Cavalier-Smith, T. (2004). Only six kingdoms of life. Proc. R. Soc. Lond. B, 271, 1251-1262.

Christie, P. J., Vogel, J. P. (2000). Bacterial type IV secretion: Conjugation systems adapted to deliver effector molecules to host cells. Trends Microbiol., 8, 354-360.
Cirillo, J. D., Falkow, S., Tompkins, L. S., Bermudez, L. E. (1997). Interaction of Mycobacterium avium with environmental amoebae enhances virulence. Infect. Immun., 65, 3759-3767.

Collingro, A., Poppert, S., Heinz, E., Schmitz-Esser, S., Essig, A., Schweikert, M., Wagner, M., Horn, M. (2005). Recovery of an environmental chlamydia strain from activated sludge by co-cultivation with Acanthamoeba spp. Microbiology, 151, 301-309.

Dalebroux, Z. D., Edwards, R. L., Swanson, M. S. (2009). Spot governs Legionella pneumophila differentiation in host macrophages. Mol. Microbiol., 71, 640-658.

Declerck, P., Behets, J., Margineanu, A., Van Hoef, V., De Keersmaecker, B., Ollevier, F. (2009). Replication of Legionella pneumophila in biofilms of water distribution pipes. Microbiol. Res., 164, 593-603.

Diamond, L. S., Mattern, C. F. T., Bartgis, L. I. (1972). Viruses of Entamoeba histolytica I. Identification of transmissible virus-like agents. J. Virol., 9, 326-341.

Dupuy, M., Mazoua, S., Berne, F., Bodet, C., Garrec, N., Herbelin, P., Menard-Szczebara, F., Oberti, S., Rodier, M. H., Soreau, S., Wallet, F., Hechard, Y. (2011). Efficiency of water disinfectants against Legionella pneumophila and Acanthamoeba. Water Res., 45 (3), 1087-1094.

Greub, G., La Scola, B., Raoult, D. (2004). Amoebae-resisting bacteria isolated from human nasal swabs by amoebal coculture. Emerg. Infect. Dis., 10 (3), 470-477.

Greub, G., Raoult, D. (2004). Microorganisms resistant to free-living amoebae. Clin. Microbiol. Rev., 17, 413-433.

Grillot-Courvalin, C., Goussard, S., Huetz, F., Ojcius, D. M., Courvalin, P. (1998). Functional gene transfer from intracellular bacteria to mammalian cells. Nat. Biotechnol., 16, 862-866.

Hackstadt, T., Williams, J. C. (1983). pH dependence of the Coxiella burnetii glutamate transport system. J. Bacteriol., 154, 598-603.

Harb, O. S., Gao, L. Y., Kwaik, Y. A. (2000). From protozoa to mammalian cells: A new paradigm in the life cycle of intracellular bacterial pathogens. Environ. Microbiol., 2, 251-265.

Horn, M., Wagner, M. (2004). Bacterial endosymbionts of free-living amoebae. J. Eukaryot. Microbiol., 51 (5), 509-514.

Huws, S. A., Morley, R. J., Jones, M. V., Brown, M. R. W., Smith, A. W. (2008). Interactions of some common pathogenic bacteria with Acanthamoeba polyphaga. FEMS Microbiol. Lett., 282, 258-265.

Iseberg, R. R., O'connor, T. J., Heidtman, M. (2009). The Legionella pneumophila replication vacuole: Making a cosy niche inside host cells. Nat. Rev. Microbiol., 7, 13-24.

Jürgens, K., Matz, C. (2002). Predation as a shaping force for the phenotypic and genotypic composition of planktonic bacteria. Antonie van Leeuwenhoek, 81, 413-434.

Kebbi-Beghdadi, C., Greub, G. (2014). Importance of amoebae as a tool to isolate amoeba-resisting microorganisms and for their ecology and evolution: The Chlamydia paradigm. Environ. Microbiol. Rep., 6, 309-324.

Koval, S. F. (1993). Predation on bacteria possessing S-layers. In: Beveridge, T. J., Beveridge, T. J. (eds.). Advances in Bacterial Paracrystalline Surface Layers. Plenum Press, New York, pp. 85-92.

Lambrecht, E., Baré, J., Van Damme, I., Bert, W., Sabbe, K., Houf, K. (2013). Behavior of Yersinia enterocolitica in the presence of the bacterivorous Acanthamoeba castellanii. Appl. Environ. Microbiol., 79, 6407-6413.

Laskowski-Arce, M. A., Orth, K. (2008). Acanthamoeba castellanii promotes the survival of Vibrio parahaemolyticus. Appl. Environ. Microbiol., 74, 7183-7188.

Lorenzo-Morales, J., Martínez-Carretero, E., Batista, N., Álvarez-Marín, J., Bahaya, Y., Walochnik, J., Valladares, B. (2007). Early diagnosis of amoebic keratitis due to a mixed infection with Acanthamoeba and Hartmannella. Parasitol. Res., 102 (1), 167-169.

Mattern, C. F. T., Diamond, L. S., Daniel, W. A. (1972). Viruses of Entamoeba histolytica. II. Morphogenesis of the polyhedral particle 
(ABRM 2 aHK-9) äB-301 and the filamentous agent (ABRM) 2 aHK-9. $J$. Virol., 9, 342-358.

Matz, C., Bergfeld, T., Rice, S. A., Kjellberg, S. (2004). Microcolonies, quorum sensing and cytotoxicity determine the survival of Pseudomonas aeruginosa biofilms exposed to protozoan grazing. Environ. Microbiol., 6, $218-226$

Matz, C., Jürgens, K. (2003). Interaction of nutrient limitation and protozoan grazing determines the phenotypic structure of a bacterial community. Microb. Ecol., 45, 384-398.

Matz, C., Kjelleberg, S. (2005). Off the hook - how bacteria survive protozoan grazing. Trends Microbiol., 13, 302-307.

Matz, C., Nouri, B., McCarter, L., Martinez-Urtaza, J. (2011). Acquired type III secretion system determines environmental fitness of epidemic Vibrio parahaemolyticus in the interaction with bacterivorous protists. PLoS ONE, 6, e20275.

Matz, C., Webb, J. S., Schupp, P. J., Phang, S. Y., Penesyan, A., Egan, S., Steinberg, P., Kjelleberg, S. (2008). Marine biofilm bacteria evade eukaryotic predation by targeted chemical defense. PLOS ONE, 3 (7), e2744.

Mella, C., Medina, G., Flores-Martin, S., Toledo, Z., Simaluiza, R. J., Perez-Perez, G., Fernandez, H. (2016). Interaction between zoonotic bacteria and free living amoebas. A new angle of an epidemiological polyhedron of public health importance? Arch. Med. Vet., 48, 1-10.

Molmeret, M., Horn, M., Wagner, M., Santic, M., Kwaik, Y. A. (2005). Amoebae as training grounds for intracellular bacterial pathogens. Appl. Environ. Microbiol., 71, 20-28.

Moreira, D., Brochier-Armanet, C. (2008). Giant viruses, giant chimeras: The multiple evolutionary histories of Mimivirus genes. BMC Evol. Biol., 8,12

Pagnier, I., Raoult, D., La Scola, B. (2008). Isolation and identification of amoeba-resisting bacteria from water in human environment by using an Acanthamoeba polyphaga co-culture procedure. Environ. Microbiol., 10 (5), 1135-1144.

Rolston, K. V. I., Winans, R., Rodriguez, S., Miller, R. A., Minshew, B. N. (1989). Blastocystis hominis: Pathogen or not? Rev. Infect. Dis., 11, 661-663.

Rowbotham, T. J. (1998). Isolation of Legionella pneumophila serogroup 1 from human feces with use of amebic cocultures. Clin. Infect. Dis., 26, $502-503$.

Saeed, A., Abd, H., Edvinsson, B., Sandström, G. (2009). Acanthamoeba castellanii an environmental host for Shigella dysenteriae and Shigella sonnei. Arch. Microbiol., 191, 83-88.

Saeed, A., Johansson, D., Sandström, G., Abd, H. (2012). Temperature depended role of Shigella flexneri invasion plasmid on the interaction with Acanthamoeba castellanii. Int. J. Microbiol., ID: 917031.

Salah, I. B., Ghigo, E., Drancourt, M. (2009). Free-living amoebae, a training field for macrophage resistance of mycobacteria. Clin. Microbiol. Infect., 15 (10), 894-905.

Schmitz-Esser, S., Tischler, P., Arnold, R., Montanaro, J., Wagner, M., Rattei, T., Horn, M. (2010). The genome of the amoeba symbiont "Candidatus Amoebophilus asiaticus" reveals common mechanisms for host cell interaction among amoeba-associated bacteria. J. Bacteriol., 192 (4), 1045-1057.
Schmitz-Esser, S., Toenshoff, E. R., Haider, S., Heinz, E., Hoenninger, V. M., Wagner, M., Horn, M. (2008). Diversity of bacterial endosymbionts of environmental Acanthamoeba isolates. Appl. Environ. Microbiol., 74 (18), 5822-5831.

Schuster, F. L. (2002). Cultivation of pathogenic and opportunistic free-living amoebas. Clin. Microbiol. Rev., 15 (3), 342-354.

Schuster, F. L., Dunnebacke, T. H., Booton, G. C., Yagi, S., Kohlmeier, C. K., Glaser, C. (2003). Environmental isolation of Balamuthia mandrillaris associated with a case of amebic encephalitis. J. Clin. Microbiol., 41, 3175-3180.

Schuster, F. L., Visvesvara, G. S. (2004). Free-living amoebae as opportunistic and non-opportunistic pathogens of humans and animals. Int. J. Parasitol., 34, 1001-1027.

Siddiqui, R., Khan, N. A. (2012a). War of the microbial worlds: Who is the beneficiary in Acanthamoeba-bacterial interactions? Exp. Parasitol., 130, 311-313.

Siddiqui, R., Khan, N. A. (2012b). Biology and pathogenesis of Acanthamoeba. Parasit. Vectors, 5, 6.

Snelling, W. J., Moore, J. E., McKenna, J. P., Lecky, D. M., Dooley, J. S. G. (2006). Bacterial-protozoa interactions; an update on the role these phenomena play towards human illness. Microbes Infect., 8, 578-587.

Taylor, M., Ross, K., Bentham, R. (2009). Legionella, protozoa, and biofilms: Interactions within complex microbial systems. Microb. Ecol., 58, 538-547.

Tezcan-Merdol, D., Ljungstrom, M., Winiecka-Krusnell, J., Linder, E., Engstrand, L., Rhen, M. (2004). Uptake and replication of Salmonella enterica in Acanthamoeba rhysodes. Appl. Environ. Microbiol., 70, 3706-3714.

Thom, S., Warhurst, T., Drasar, B. S. (1992). Association of Vibrio cholerae with fresh water amoebae. J. Med. Microbiol., 36, 303-306.

Thomas, V., Greub, G. (2010). Amoeba/amoebal symbiont genetic transfers: Lessons from giant virus neighbours. Intervirology, 53, 254-267.

Thomas, V., Herrera-Rimann, K., Blanc, D. S., Greub, G. (2006). Biodiversity of amoebae and amoeba-resisting bacteria in a hospital water network. Appl. Environ. Microbiol., 72, 2428-2438.

Vaerewijck, M. J. M., Baré, J., Lambrecht, E., Sabbe, K., Houf, K. (2014). Interactions of foodborne pathogens with free-living protozoa: Potential consequences for food safety. Compr. Rev. Food Sci. Food Saf., 13, 924-944.

Vaerewijck, M. J. M., Sabbe, K., Van Hende, J., Bare, J., Houf., K. (2010). Sampling strategy, occurrence and diversity of free-living protozoa in domestic refrigerators. J. Appl. Microbiol., 109, 1566-1578.

Vaerewijck, M. J. M., Sabbe, K., Baré, J., Houf, K. (2008). Microscopic and molecular studies of the diversity of free-living protozoa in meat-cutting plants. Appl. Environ. Microbiol., 74, 5741-5749.

Vezzulli, L., Pruzzo, C., Huq, A., Cowell, R. (2010). Environmental reservoirs of Vibrio cholera and their role in cholera. Environ. Microbiol. Rep., 2, 27-33.

Xi, C., Zhang, Y., Marrs, C. F., Ye, W., Simon, C., Foxman, B., Nriagu, J. (2009). Prevalence of antibiotic resistance in drinking water treatment and distribution systems. Appl. Environ. Microbiol., 75, 5714-5718.

Received 27 November 2016

Accepted in the final form 3 February 2017

\section{MIJIEDARBĪBA STARP BRĪVI DZĪVOJOŠĀM AMĒBĀM UN TO IEKŠŠŪNU BAKTĒRIJĀM}

Vairākas patogēno baktēriju sugas ir rezistentas pret brīvi dzīvojošām amēbām un pat pret makrofāgu sagremošanu. Baktērijas turpina adaptēties saimniekorganisma vidē un attīsta jaunus izdzīvošanas mehānismus. Baktērijas var izmantot brīvi dzīvojošās amēbas kā rezervuārus, mediatorus, infekcijas ceḷus, "bioloǵiskās treniṇvietas" un evolucionāro šūpuli, vai mijiedarbība var kḷūt par ciešām endosimbiozes attiecībām. Šobrīd nav aprakstìti un nav zināmi visi mijiedarbības mehānismi, daḷa no tiem ir tikai pieminēti un trūkst sīkāka apraksta. Turklāt pētījumos par brīvi dzīvojošo amēbu un to iekššūnu baktēriju mijiedarbību ir nepieciešams izmantot lielāku paraugu skaitu un amēbu kopkultūras nekā līdz šim, lai iegūtu precīzākus un ticamākus datus par patogēnajām baktērijām un to mijiedarbības 